\title{
Patterns, trends, and factors associated with contraceptive use among adolescent girls in Zambia (1996 to 2014): a multilevel analysis
}

Mumbi Chola ${ }^{1,2^{*}}$ (D, Khumbulani Hlongwana ${ }^{1}$ and Themba G. Ginindza ${ }^{1}$

\begin{abstract}
Background: Despite high levels of pregnancy and childbearing among adolescents in Africa, contraceptive use remains low. Examining variations in contraceptive use among adolescent girls is vital for informing programs to improve contraceptive utilisation among this segment of the population. This study aimed to examine the patterns, trends, and factors associated with contraceptive use among adolescents in Zambia over the period 1996-2014.

Methods: The study involved an analysis of data from 1996, 2001/2, 2007 and 2013/14 Zambia Demographic and Health Surveys focusing on adolescent girls aged 15-19years. Analysis entailed descriptive statistics and estimation of multilevel logistic regression models examining variations in contraceptive use among adolescent girls over time. Estimates with $p$-values less than 0.05 were considered statistically significant.

Results: Results showed that contraceptive use remains low and ranged from 7.6\% in 1996 to 10.9\% in 2013/14, reflecting a change of 3.3 percentage points over 18 years. Over the 18 years, contraceptive use was significantly associated with age, level of education, and marital status. Older adolescent girls and those with higher levels of education were significantly more likely to use contraception compared to younger ones and those with lower levels of education. Although initially significant (AOR 0.556, 95\% Cl 0.317, 0.974 in 1996), rural-urban differences disappeared between 2001/2 and 2007 but re-emerged in 2013/14 (AOR 0.654, 95\% Cl 0.499, 0.859). Across all survey years, adolescents who were married or living with a partner were significantly more likely to use contraceptives compared to those who were not married.
\end{abstract}

Conclusions: The findings suggest the need for targeted interventions to improve contraceptive use among sexually active adolescent girls in the country in general, and those who are disadvantaged in particular.

Keywords: Adolescent girls, Contraceptive use, Patterns and trends, Multilevel analysis, Zambia

\footnotetext{
* Correspondence: mumbi24@gmail.com

${ }^{1}$ Department of Public Health Medicine, School of Nursing and Public Health,

University of KwaZulu Natal, Durban, South Africa

${ }^{2}$ Department of Epidemiology \& Biostatistics, School of Public Health,

University of Zambia, Lusaka, Zambia
}

C The Author(s). 2020 Open Access This article is licensed under a Creative Commons Attribution 4.0 International License, which permits use, sharing, adaptation, distribution and reproduction in any medium or format, as long as you give appropriate credit to the original author(s) and the source, provide a link to the Creative Commons licence, and indicate if changes were made. The images or other third party material in this article are included in the article's Creative Commons licence, unless indicated otherwise in a credit line to the material. If material is not included in the article's Creative Commons licence and your intended use is not permitted by statutory regulation or exceeds the permitted use, you will need to obtain permission directly from the copyright holder. To view a copy of this licence, visit http://creativecommons.org/licenses/by/4.0/ The Creative Commons Public Domain Dedication waiver (http://creativecommons.org/publicdomain/zero/1.0/) applies to the data made available in this article, unless otherwise stated in a credit line to the data. 


\section{Background}

The World Health Organisation (WHO) estimated that every year, approximately 21 million girls between the ages of 15 and 19 years, and 2 million girls aged below 15 years become pregnant in developing regions, with an estimated 16 million girls between ages 15 and 19 years and 2.5 million girls below the age 16 years giving birth [1]. Approximately half of these pregnancies (49\%), reported among adolescents between ages 15-19 who live in low-income regions, are unintended, and over $50 \%$ result in abortions, usually under unsafe conditions [2]. WHO further states that although the global birth rate among adolescents reduced to 47 births per 1000 women in 2015 from 65 births per 1000 women in 1990, the adolescent population continues to grow globally and adolescent pregnancies are also projected to increase by 2030, with West and Central Africa and Eastern and Southern Africa experiencing the most substantial increases [1]. Projections also show that the number of adolescent mothers will reach a high of 86 million by 2030 [3].

Pregnancies among adolescent girls have serious consequences which can significantly affect the lives of the adolescent mothers and those of the children. Early and unintended pregnancies among adolescents have been associated with adverse health, educational, social, and economic outcomes [4]. The impact on adolescent mothers includes risks of maternal death, illness, and disability such as obstetric fistula, complications of unsafe abortion, sexually transmitted infections; including HIV, and health risks to infants [5]. About 70,000 adolescent girls in low-income countries (LICs) die annually of causes related to pregnancy and childbirth [5]. Among adolescent girls aged 15-19 years in LICs, pregnancy and childbirth complications are the second leading cause of death, and babies born to these mothers have increased health risks compared to those born to older women [2]. Early and unintended pregnancy disrupts adolescent girls' schooling, thus affecting their future economic opportunities, including reducing job market opportunities $[5,6]$. The effects of adolescent childbearing also extend to the health of babies with higher perinatal deaths and low birth weight among children born to mothers aged below 20 years [5-7].

Despite the high rates of pregnancies and births among adolescents, contraceptive use among this segment of the population remains low globally, particularly in LICs, such as those in Africa [8-10]. Evidence shows that contraceptive prevalence rate (CPR) among adolescent females aged 15-19 years in LICs is $21 \%$ for all methods (modern and traditional) [8, 11, 12]. The low use of contraception among adolescents occurs against the backdrop of evidence that using family planning methods has benefits that could reduce some of the negative consequences of adolescent pregnancy and childbearing. These benefits include the freedom to decide how many children to have and child spacing, improvements in health-related outcomes, such as a reduction in maternal mortality and infant mortality [13-15] and improvements in schooling and economic outcomes [16, 17].

Studies show that various factors influence adolescents' decision making regarding whether or not to use contraceptives. These include individual; family, societal or peer; health system; and cultural and religious factors. This paper focuses on individual-level factors, which include education $[10,18,19]$, knowledge of contraceptives [20, 21], fear, shame, myths and stigma [22, 23] and fear of side effects and adverse reactions [24, 25].

In Zambia, contraceptive use among adolescents remains low despite the evidence showing almost universal knowledge of at least one modern contraceptive method [26]. Statistics show that contraceptive prevalence among women 15-49years has been increasing over time in the country. Estimates, for instance, show that use of any method among currently married women increased from $15.2 \%$ in 1992 to $49.0 \%$ in $2013-14$ while use of modern methods increased from 8.9 to $44.8 \%$ over the same period [26]. Among adolescents, contraceptive use remains low with only $10.2 \%$ using any modern contraceptive method in 2013/14 [26]. There is limited understanding of the patterns and trends of contraceptive use among adolescents and associated individual-level factors and how these have changed over the past two decades. The aim of this study was to examine the patterns, trends, and factors associated with contraceptive use among adolescents in Zambia over the period 1996 to 2014.

\section{Methods}

This study involved an analysis of cross-sectional data from four Zambia Demographic and Health Surveys (1996, 2001/2, 2007 and 2013/14). The Zambia Demographic and Health Survey (ZDHS) is a nationally representative sample survey of Zambian households. The main objective of the ZDHS is to provide information on fertility levels and trends, mortality, family planning, as well as indicators on maternal and child health including HIV/AIDS [26]. The sample for the ZDHS is designed to provide estimates of population and health indicators at the national and provincial levels [26]. The sample design allows for specific indicators, such as contraceptive use, to be calculated for all provinces in Zambia. The sampling frame used for the ZDHS is usually adopted from the Census of Population and Housing of the Republic of Zambia $(\mathrm{CPH})$ provided by the Central Statistical Office. 
A representative sample of households was drawn for all the ZDHS surveys using a two-stage stratified cluster sample design, with Enumeration Areas (EAs) (or clusters) selected during the first stage and households selected during the second stage. The sample was stratified in two stages from the CPH frames (1990, 2000 and 2010). Stratification was achieved by dividing every province into urban and rural areas. Provinces were stratified into 18 strata in earlier surveys and 20 strata in the 2013/14 survey. Samples were selected independently in every stratum through a two-stage selection process. Stratification and proportional allocation were achieved, at all lower geographical/administrative levels, by sorting the sampling frame according to the geographical/administrative order and using a probability proportional to size selection process in the first stage. All women and men aged, 15-49 and 15-59 respectively, who were either permanent residents of the households in the sample or were visitors present in the household on the night before the survey, were eligible for interview [26].

The target population in this study included adolescent girls aged 15-19 years captured in the ZDHS surveys. All those who responded to the question on current contraceptive method were included in the analysis. Current use of a contraceptive method, which was the dependent variable, was recoded into a binary outcome, those currently using and those not using any method. Explanatory variables included in the analysis were age, type of place of residence, province, highest level of education, marital status at the time of interview, literacy, and knowledge of any contraceptive method (Table 1). Since the ZDHS involved more than one level of stratification, analysis took into account cluster and household variables. Adolescents who had never had sex were excluded from the analysis.
Data from the four ZDHS surveys were combined by appending the data sets from 1996, 2001/2 and 2007 to the 2013/14 ZDHS. We started by conducting descriptive analysis and presented the results as proportions. Where appropriate, Chi-square and Fischer's exact tests were used to test for the significance of association between the outcome and explanatory variables. We then conducted multilevel multivariate logistic regression analysis - factoring in random effects-to determine the predictors of contraceptive use. Analysis was conducted using Stata 15/MP (StataCorp LLC) and estimates with $p$-value less than 0.05 were considered statistically significant.

\section{Results}

\section{Sample characteristics}

A total of 9072 adolescent girls were included in the analysis across the four ZDHS surveys. The majority (41\%) were from the 2013/14 ZDHS while $18 \%$ were from the 2007 survey, 20\% from the 2001/2 survey and $22 \%$ from the 1996 survey. Table 2 shows the distribution of adolescent girls included in the analysis by background characteristics across the survey years.

Overall, contraceptive use over the 18 years has been low, with only $9.8 \%$ of adolescent girls aged between 15 and 19-years using contraceptives (Table 2). This ranged from $7.6 \%$ in 1996 to $10.9 \%$ in $2013 / 14$, reflecting a 3.3 percentage point change over 18 years $(p<0.01)$. The distribution of respondents across ages ranged from 18.1 to $23.2 \%$ over the survey years. Regarding marital status, the proportion of adolescents who reported being married declined from $24.8 \%$ in 1996 to $15.1 \%$ in 2013 / 14 (Table 2). However, 19.3\% of adolescent girls interviewed over the 18-year period from 1996 to 2014 were married at the time of the survey. Rural and urban distribution showed that in 1996 and 2001/2, the

Table 1 Definition of variables

\begin{tabular}{|c|c|}
\hline Variable & Definition and measurement \\
\hline $\begin{array}{l}\text { Current Contraceptive } \\
\text { Use }\end{array}$ & Contraception use: $0=$ Not using a method; $1=$ Using a method \\
\hline $\begin{array}{l}\text { Knowledge of Any } \\
\text { Method }\end{array}$ & Knowledge of any modern contraceptive method: $0=$ Knows no method; 1 = Knows modern methods" \\
\hline Age & Respondent's current age in competed years: ranges from 15 to 19 \\
\hline Current Marital Status & Marital status of the respondent: $0=$ Never in Union; $1=$ Married/Living with Partner; $2=$ Widowed/Separated/Divorced" \\
\hline Residence & Type of place of residence: $0=$ Urban; 1 = Rural \\
\hline Province & $\begin{array}{l}\text { Province or region of residence: } 1=\text { Central; } 2=\text { Copperbelt; } 3=\text { Eastern; } 4=\text { Luapula; } 5=\text { Lusaka; } 6=\text { Muchinga; } 7=\text { Northern; } \\
8=\text { North Western; } 9=\text { Southern; } 10=\text { Western }\end{array}$ \\
\hline $\begin{array}{l}\text { Highest Educational } \\
\text { Level }\end{array}$ & Highest level of education attained: 0 = No Education; 1 = Primary; 2 = Secondary \& Higher \\
\hline Literacy & $\begin{array}{l}\text { Whether a respondent who attended primary schooling can read a whole or part of a sentence: } 0=\text { Cannot read at all; } 1= \\
\text { Able to read only parts of sentence; } 2=\text { Able to read whole sentence }\end{array}$ \\
\hline Currently working & Whether the respondent was currently working (at the time of the survey): $0=\mathrm{No} ; 1=$ Yes \\
\hline
\end{tabular}


Table 2 Distribution of adolescent girls by background characteristics and survey year, ZDHS 1996-2013/14

\begin{tabular}{|c|c|c|c|c|c|}
\hline \multirow[t]{2}{*}{ Variable } & ZDHS 96 & ZDHS 2001/2 & ZDHS 2007 & ZDHS 2013/14 & Total \\
\hline & $\mathbf{N}=1982$ & $\mathbf{N}=1806$ & $\mathbf{N}=1598$ & $\mathbf{N}=2686$ & $\mathbf{N}=9072$ \\
\hline \multicolumn{6}{|l|}{ Current Contraceptive Use } \\
\hline No & $1831(92.4 \%)$ & $1630(90.3 \%)$ & $1424(89.1 \%)$ & $3296(89.4 \%)$ & $8181(90.2 \%)$ \\
\hline Yes & $151(7.6 \%)$ & $176(9.8 \%)$ & $174(10.6 \%)$ & $390(10.9 \%)$ & $891(9.8 \%)$ \\
\hline \multicolumn{6}{|l|}{ Knowledge of Any Modern Method } \\
\hline Knows no method & $247(12.5 \%)$ & $127(7.0 \%)$ & $150(9.4 \%)$ & $162(4.4 \%)$ & $686(7.6 \%)$ \\
\hline Knows modern method & $1728(87.5 \%)$ & 1677 (93.0\%) & $1447(90.6 \%)$ & $3519(95.6 \%)$ & $8371(92.4 \%)$ \\
\hline \multicolumn{6}{|l|}{ Age } \\
\hline 15 Years & $395(19.9 \%)$ & $372(20.6 \%)$ & $370(23.2 \%)$ & 735 (19.9\%) & $1872(20.6 \%)$ \\
\hline 16 Years & 419 (21.1\%) & $326(18.1 \%)$ & $330(20.7 \%)$ & $759(20.6 \%)$ & $1834(20.2 \%)$ \\
\hline 17 Years & $369(18.6 \%)$ & $325(18.0 \%)$ & $303(19.0 \%)$ & $674(18.3 \%)$ & $1671(18.8 \%)$ \\
\hline 18 Years & $404(20.4 \%)$ & $406(22.5 \%)$ & $299(18.7 \%)$ & $774(21.0 \%)$ & $1883(20.8 \%)$ \\
\hline 19 Years & $395(19.9 \%)$ & 377 (20.9\%) & $296(18.5 \%)$ & $744(20.2 \%)$ & $1812(20.0 \%)$ \\
\hline \multicolumn{6}{|l|}{ Current Marital Status } \\
\hline Never Married & $1435(74.2 \%)$ & 1307 (72.4\%) & $1302(81.5 \%)$ & $3058(83.0 \%)$ & $7102(78.3 \%)$ \\
\hline Married/Living with Partner & $501(25.3 \%)$ & 449 (24.9\%) & $270(16.9 \%)$ & $572(15.5 \%)$ & $1792(19.8 \%)$ \\
\hline Widowed/Separated/Divorced & $46(2.3 \%)$ & $50(2.8 \%)$ & $26(1.6 \%)$ & $56(1.5 \%)$ & $178(2.0 \%)$ \\
\hline \multicolumn{6}{|l|}{ Residence } \\
\hline Urban & $799(40.3 \%)$ & 639 (35.4\%) & $809(50.6 \%)$ & $1850(50.2 \%)$ & $4097(45.2 \%)$ \\
\hline Rural & $1183(59.7 \%)$ & $1167(64.6 \%)$ & $789(49.4 \%)$ & $1836(49.8 \%)$ & $4975(454.8 \%)$ \\
\hline \multicolumn{6}{|l|}{ Province } \\
\hline Central & $170(8.6 \%)$ & $223(12.4 \%)$ & $152(9.5 \%)$ & $327(8.9 \%)$ & $872(9.6 \%)$ \\
\hline Copperbelt & $309(15.6 \%)$ & $235(13.0 \%)$ & $190(11.9 \%)$ & 417 (11.3\%) & $1151(12.7 \%)$ \\
\hline Eastern & $244(12.3 \%)$ & $192(10.6 \%)$ & $196(12.3 \%)$ & $472(12.8 \%)$ & $1104(12.2 \%)$ \\
\hline Luapula & $242(12.2 \%)$ & $159(8.8 \%)$ & $152(9.5 \%)$ & $279(7.6 \%)$ & $832(9.2 \%)$ \\
\hline Lusaka & $274(13.8 \%)$ & 204 (11.3\%) & $224(14.0 \%)$ & $434(11.8 \%)$ & $1136(12.5 \%)$ \\
\hline Muchinga ${ }^{a}$ & - & - & - & $340(9.2 \%)$ & $1001(11.0 \%)$ \\
\hline Northern & $204(10.3 \%)$ & $288(16.0 \%)$ & $169(10.6 \%)$ & $352(9.6 \%)$ & $821(9.1 \%)$ \\
\hline North western & $114(5.8 \%)$ & $198(11.0 \%)$ & $157(9.8 \%)$ & $381(10.3 \%)$ & $943(10.4 \%)$ \\
\hline Southern & $205(10.3 \%)$ & $166(9.2 \%)$ & $191(12.0 \%)$ & $377(10.2 \%)$ & 905 (10.0\%) \\
\hline Western & $220(11.1 \%)$ & $141(7.8 \%)$ & $167(10.5 \%)$ & $307(8.3 \%)$ & 307 (3.4\%) \\
\hline \multicolumn{6}{|l|}{ Highest Educational Level } \\
\hline No education & $174(8.8 \%)$ & $158(8.8 \%)$ & $69(4.3 \%)$ & $69(1.9 \%)$ & $470(5.2 \%)$ \\
\hline Primary & $1254(63.3 \%)$ & 1073 (59.5\%) & $756(47.5 \%)$ & 1418 (38.6\%) & $4501(49.8 \%)$ \\
\hline Secondary & $553(27.9 \%)$ & $574(31.8 \%)$ & 767 (48.2\%) & $2183(59.5 \%)$ & $4077(45.0 \%)$ \\
\hline \multicolumn{6}{|l|}{ Literacy $^{\mathrm{b}}$} \\
\hline Cannot Read at All & - & 765 (42.8\%) & $386(24.6 \%)$ & $750(20.5 \%)$ & $1901(27.1 \%)$ \\
\hline Able to Read Only Parts of Sentence & - & $188(10.5 \%)$ & $151(9.6 \%)$ & $283(7.7 \%)$ & $622(8.9 \%)$ \\
\hline Able to Read Whole Sentence & - & $834(46.7 \%)$ & $1032(64.8 \%)$ & $2621(71.7 \%)$ & $448764.0 \%)$ \\
\hline
\end{tabular}

a - Data on Muchinga province not available for 1996, 2001/2 and 2007 surveys. Muchinga only became a province in 2011

$b^{b}$ - Data on literacy was not collected in the 1996 ZDHS

majority of the respondents were from rural areas (59.7 and 64.6\% respectively). However, in 2007 and 2013/14, the distribution was almost even $(50.6 \%$ vs $49.4 \%$ in 2007 and $50.2 \%$ vs $49.8 \%$ in $2013 / 14$ ). The provincial distribution shows that overall, Copperbelt (12.7\%), Lusaka (12.5\%) and Eastern (12.2\%) provinces had the highest proportion of adolescent girls; with Western province recording the lowest proportion of $3.4 \%$. 
There were also changes in the distribution of adolescent girls by highest level of education. In 1996 and $2001 / 2$, the majority of respondents had attained primary school level education (63.3 and $59.4 \%$ respectively) while in 2007 and 2013/14, the majority had attained secondary level education (48.2 and 59.3\% respectively; Table 2). Knowledge of modern contraceptive methods also increased over the reference period. In 1996, $87.7 \%$ of adolescents reported knowing modern contraceptive methods, which increased to $95.5 \%$ in $2013 / 14$. Concerning literacy, the proportion of adolescents who could not read at all declined from $42.4 \%$ in $2001 / 2$ to $20.4 \%$ in $2013 / 14$. In contrast, the proportion of adolescents who could read whole sentences increased from $46.2 \%$ in $2001 / 2$ to $71.1 \%$ in $2013 / 14$. No data on literacy was collected in 1996.

\section{Patterns and trends in contraceptive use}

Table 3 below describes the proportions of adolescent girls aged 15-19 years who used contraceptives across the survey years.

\section{Age}

Over the period 1996 to 2013/14, contraceptive use increased significantly with age $(p=0.000)$. The proportion using contraception was highest among 19-year old and lowest among 15-year old adolescent girls across survey years (Fig. 1). However, the proportion of 19-year old adolescent girls using contraception declined from 25\% in 2007 to $20 \%$ in $2013 / 14$.

\section{Marital status}

Differences in contraceptive use according to marital status across the four surveys were also statistically significant $(p=0.000)$. Adolescent girls who were married or living with a partner comprised the highest proportion of contraceptive users in 1996 (17.0\%) and 2001/2 (24.3\%). From 2001/2 to 2007, the proportion of contraceptive users increased across all groups with the most increases being among those married or living with a partner $(24.3 \%$ in $2001 / 2$ to $28.5 \%$ in 2007$)$ and those who were widowed/ separated or divorced $(10.0 \%$ in $2001 / 2$ to $34.6 \%$ in 2007). By 2013/14, those who were married/living with a partner comprised the highest proportion of contraceptive users (36.4\%).

\section{Province}

Variations in contraceptive use among adolescent girls by province show that in 1996, North-Western province had the highest proportion of users $(20 \%)$ while Luapula province had the lowest (2\%; Table 3). In the 2001/2 survey, Lusaka had the highest while Central province had the lowest proportion of adolescent girls using contraception (16 and 5\%, respectively; Table 3). In 2007 and
2013/14, the proportion of adolescent girls using contraception was highest in Western province (29 and 16\%, respectively) and lowest in Luapula province (3 and 6\%, respectively). The observed differences in contraceptive use by province were statistically significant $(p=0.000)$.

\section{Residence}

Contraceptive use by urban-rural residence showed some variation over the period 1996-2013/14. Contraceptive use among urban adolescent girls increased between 1996 to $2001 / 2$ from 8.1 to $11.4 \%$ before slightly declining to $10.1 \%$ in 2007 and remaining unchanged thereafter (Table 3). Among adolescent girls in rural areas, the proportion using contraception increased between 1996 and 2007 from 7.3 to $11.8 \%$ and remained largely unchanged thereafter.

\section{Highest education level}

The proportion of adolescent girls using contraception was generally low across all levels of education. In 2007 and 2013/14, use was highest among those with primary level education (13 and 12\%, respectively), having increased from 7\% in 1996 (Table 3). Among those with no education, only $7 \%$ reported using a contraceptive method in 2013/14, which was lower than the proportion using in 2001/2 and 2007 (10\% in each case; Table 3 ). Among those with secondary level education, the proportion ranged between 9 and $11 \%$ in the period between 1996 and 2013/14 with 10\% reporting currently using contraceptives in 2013/14.

\section{Determinants of contraceptive use}

The odds of using contraceptives increased with age across all years. The odds of contraceptive use were higher among older adolescents than the younger ones across all survey years. However, significant differences were observed in 1996, 2007 and 2013/14. In 1996, adolescent girls aged 19 years were 4 times significantly more likely to use contraception compared to those aged 15 years (AOR 4.175, 95\% CI 1.377, 12.656) while in 2007 , they were twice as likely to use a method as their 15-year-old counterparts (AOR 2.667, 95\% CI 1.255, 5.668) (Table 4). Results in Table 4 showed that in 2013/ 14, 18-year olds had the highest odds of contraceptive use compared to 15-year olds (AOR 2.717, 95\% CI 1.496, 4.935.

Results from correlation analysis showed that although there were some positive and negative correlations between the factors considered in the analysis, these were not very strong (Table 5).

There were also disparities by province. In 1996, adolescent girls in North Western (AOR 6.043, 95\% CI 2.301, 15.875), Eastern (AOR 3.147, 95\% CI 1.230, 8.052), and Northern (AOR 2.871, 95\% CI 1.109, 7.437) 
Table 3 Distribution of adolescent girls aged 15-19years using contraception by background characteristics, 1996-2013/14

\begin{tabular}{|c|c|c|c|c|c|c|c|c|}
\hline \multirow[t]{2}{*}{ Current Contraceptive Use } & \multicolumn{2}{|l|}{1996} & \multicolumn{2}{|c|}{$2001 / 2$} & \multicolumn{2}{|l|}{2007} & \multicolumn{2}{|c|}{ 2013/14 } \\
\hline & $\%$ & N & $\%$ & N & $\%$ & N & $\%$ & N \\
\hline \multicolumn{9}{|l|}{ Marital Status } \\
\hline Never in union & 4.3 & 1435 & 4.7 & 1307 & 6.8 & 1302 & 5.6 & 3058 \\
\hline Married/Living with Partner & 17.0 & 416 & 24.3 & 449 & 28.5 & 270 & 36.4 & 572 \\
\hline Widowed/Separated/Divorced & 8.7 & 46 & 10.0 & 50 & 34.6 & 26 & 19.6 & 56 \\
\hline$P$-Value & 0.000 & & 0.000 & & 0.000 & & 0.000 & \\
\hline \multicolumn{9}{|l|}{ Province } \\
\hline Central & 5.3 & 170 & 5.4 & 223 & 6.6 & 152 & 9.8 & 327 \\
\hline Copperbelt & 6.5 & 309 & 11.1 & 235 & 6.3 & 190 & 6.7 & 417 \\
\hline Eastern & 9.0 & 244 & 7.3 & 192 & 13.8 & 196 & 11.0 & 472 \\
\hline Luapula & 2.1 & 242 & 13.2 & 159 & 3.3 & 152 & 5.7 & 279 \\
\hline Lusaka & 8.0 & 274 & 15.7 & 204 & 8.5 & 224 & 12.7 & 434 \\
\hline Muchinga & - & - & - & - & - & - & 7.9 & 340 \\
\hline Northern & 9.3 & 204 & 7.6 & 288 & 7.1 & 169 & 9.1 & 352 \\
\hline North western & 20.2 & 114 & 11.1 & 198 & 15.3 & 157 & 12.9 & 381 \\
\hline Southern & 4.9 & 205 & 8.4 & 166 & 8.9 & 191 & 13.5 & 377 \\
\hline Western & 9.6 & 220 & 9.2 & 141 & 28.7 & 167 & 15.6 & 307 \\
\hline$P$-Value & 0.000 & & 0.014 & & 0.000 & & 0.000 & \\
\hline \multicolumn{9}{|l|}{ Residence } \\
\hline Urban & 8.1 & 799 & 11.4 & 639 & 10.0 & 809 & 10.1 & 1850 \\
\hline Rural & 7.3 & 1183 & 8.8 & 1167 & 11.8 & 789 & 11.1 & 1836 \\
\hline$P$-Value & 0.476 & & 0.075 & & 0.255 & & 0.297 & \\
\hline \multicolumn{9}{|l|}{ Highest Education Level } \\
\hline Education & 5.8 & 174 & 10.1 & 158 & 10.1 & 69 & 7.3 & 69 \\
\hline Primary & 7.4 & 1254 & 9.2 & 1073 & 13.0 & 756 & 11.6 & 1428 \\
\hline Secondary \& Higher & 8.7 & 554 & 10.6 & 575 & 8.9 & 773 & 10.0 & 2197 \\
\hline$P$-Value & 0.407 & & 0.656 & & 0.040 & & 0.199 & \\
\hline \multicolumn{9}{|l|}{ Literacy* } \\
\hline Cannot read at all & - & & 9.9 & 765 & 15.0 & 386 & 12.5 & 750 \\
\hline Able to read only par & - & & 11.2 & 188 & 9.9 & 151 & 9.2 & 283 \\
\hline Able to read whole se & - & & 9.1 & 834 & 9.7 & 1032 & 10.1 & 2621 \\
\hline$P$-Value & & & 0.657 & & 0.015 & & 0.121 & \\
\hline
\end{tabular}

9 - Data on Muchinga province not available for 1996, 2001/2 and 2007 surveys. Muchinga only became a province in 2011.

* - Data on literacy was not collected in the 1996 ZDHS

provinces reported the highest odds of using contraceptives compared to those in Central. In 2001/2, there were significant variations between Central province and Copperbelt (AOR 2.671, 95\% CI 1.193, 5.978), Luapula (AOR 3.234, 95\% CI 1.445, 7.238), Lusaka (AOR 3.731, 95\% CI 1.671, 8.332) and North Western (AOR 2.274, $95 \%$ CI 1.041, 4.967) provinces (Table 4). In 2007, there were significant differences between Central and North Western and Western provinces. Adolescent girls in North Western and Western provinces were, respectively, 2.4 times and almost 6 times more likely to use contraceptives compared to those in Central province.
There were no significant variations in contraceptive use by province in 2013/14.

Adolescent girls in rural areas were also less likely to use contraceptives compared with their urban counterparts. There were statistically significant variations in contraceptive use by place of residence in 1996 (AOR 0.556, 95\% CI 0.317, 0.974) and 2013/14 (AOR 0.654, 95\% CI 0.499, 0.859) (Table 4). Adolescent girls with secondary or higher levels of education were significantly more likely to use contraception compared to those with no education across all survey years. From 2007 onwards, adolescent girls with primary level education, like 
30

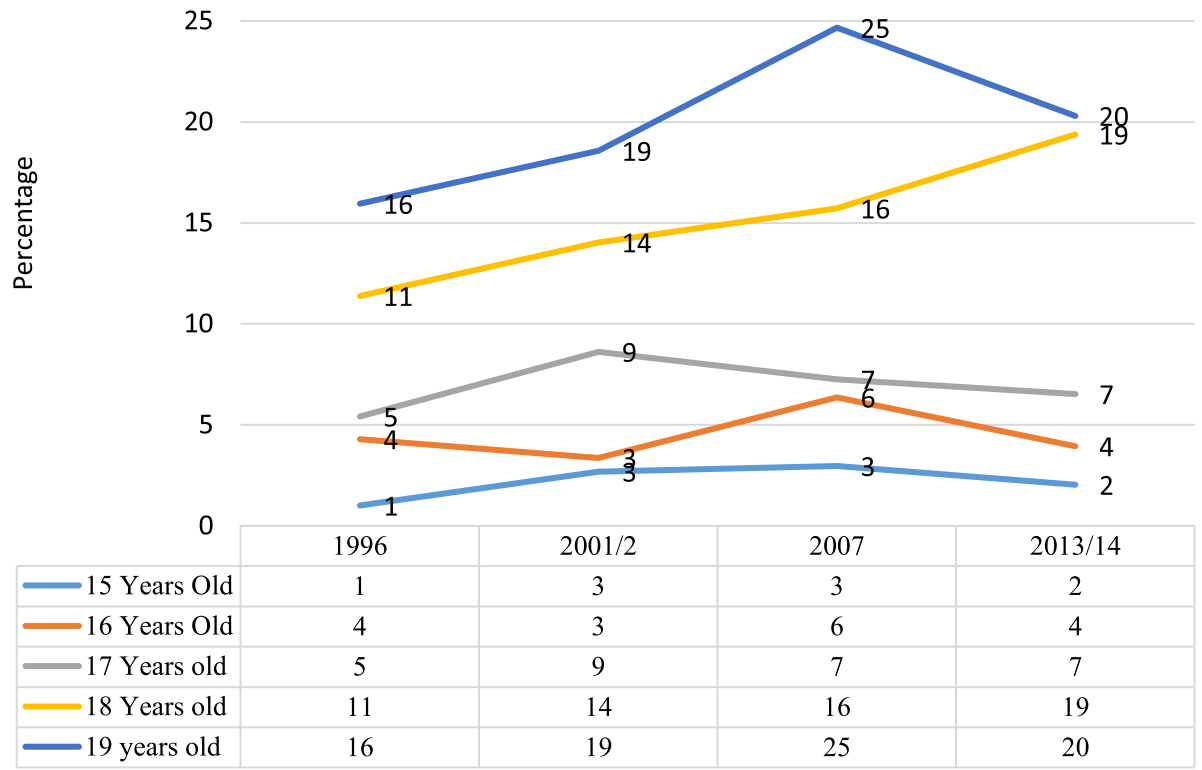

Fig. 1 Trends in Contraceptive Use by Age over the period 1999 to 2013/14

those with secondary level education, were also significantly more likely to use contraceptives compared to those with no education. Similarly, adolescent girls who were married or living with a partner were significantly more likely to use contraception than their never married counterparts across all survey years. In 2007, adolescent girls who were married or living with a partner, or were widowed, separated, or divorced were significantly more likely to use contraception than their never married counterparts.

In summary, the results show that adolescent girls who were most likely to use contraceptives were aged 18-19 years old, had secondary education or higher, and were either married or living with their partner. However, whereas initial significant urban-rural differences in contraceptive use among adolescent girls seemed to have been bridged between 2001/2 and 2007, such differences emerged in 2013/14.

Random-effects results from the multilevel model show that in 1996, 9\% of variability in contraceptive use among adolescent girls was explained by inter-cluster variations while in 2013/14, inter-cluster variability explained only $2 \%$ of the variations. This shows that over time, variations in contraceptive use among adolescent girls across different geographic clusters were becoming less important compared to individual-level variations.

\section{Discussion}

Contraceptive use among adolescent girls in Zambia remained low over the period 1996-2014 although knowledge of at least one modern method is almost universal. Results from this study showed that in recent years, age, education, residence, marital status, and working status were significantly associated with contraceptive use among adolescent girls. Significant ruralurban differences, which occurred in early years but disappeared in subsequent years, re-emerged in recent years while provincial disparities were bridged. In addition, the odds of using contraceptives increased as adolescent girls grew older and achieved higher levels of education. Furthermore, adolescent girls who were married or living with their partners were significantly more likely to use contraceptives compared with those who were never married.

The low contraceptive use among adolescents could be due to challenges with access to contraception and the actual use of methods. Health system issues, such as lack of adolescent-friendly health services, as well as health care worker attitudes [22], can deter adolescents from accessing contraceptives, particularly from health centres. Lack of access to contraceptive and family planning services at heath facilities affects the kind of information that adolescents have. Studies have shown that in addition to low contraceptive use and limited access to information and services, adolescents have poor knowledge of family planning [27]. Adolescents' primary source of information was usually their peers, and the information received from such sources was mostly untrustworthy and distorted [28], thus perpetuating myths and misconceptions about contraception. The low use of 
Table 4 Odds ratios from multilevel logistic regression analysis examining variations in current use of contraception among adolescent girls aged 15-19 years in Zambia, ZDHS 1996-2013/14

\begin{tabular}{|c|c|c|c|c|c|c|c|c|c|c|c|c|c|c|c|c|}
\hline \multirow[b]{2}{*}{$\begin{array}{l}\text { Current Contraceptive } \\
\text { Use }\end{array}$} & \multicolumn{4}{|c|}{$\begin{array}{l}1996 \\
(\boldsymbol{n}=1181)\end{array}$} & \multicolumn{4}{|c|}{$\begin{array}{l}2001 / 2 \\
(\boldsymbol{n}=1042)\end{array}$} & \multicolumn{4}{|c|}{$\begin{array}{l}2007 \\
(\boldsymbol{n}=795) \\
\end{array}$} & \multicolumn{4}{|c|}{$\begin{array}{l}2013 / 14 \\
(\boldsymbol{n}=1879)\end{array}$} \\
\hline & $\mathrm{AOR}$ & $\begin{array}{l}p- \\
\text { values }\end{array}$ & {$[95 \%$} & $\mathrm{Cl}]$ & $\mathrm{AOR}$ & $\begin{array}{l}p- \\
\text { values }\end{array}$ & {$[95 \%$} & $\mathrm{Cl}]$ & $\mathrm{AOR}$ & $\begin{array}{l}p- \\
\text { values }\end{array}$ & {$[95 \%$} & $\mathrm{Cl}]$ & $\mathrm{AOR}$ & $\begin{array}{l}p^{-} \\
\text {values }\end{array}$ & {$[95 \%$} & $\mathrm{Cl}]$ \\
\hline \multicolumn{17}{|l|}{ Age } \\
\hline 15 & 1.000 & & & & 1.000 & & & & 1.000 & & & & 1.000 & & & \\
\hline 16 & 2.252 & 0.171 & $(0.705$ & 7.194) & 0.494 & 0.139 & $(0.195$ & 1.256) & 1.063 & 0.885 & $(0.464$ & $2.435)$ & 1.049 & 0.889 & $(0.534$ & 2.063) \\
\hline 17 & 1.733 & 0.352 & $(0.544$ & $5.521)$ & 0.768 & 0.524 & $(0.342$ & 1.728) & 0.762 & 0.516 & $(0.335$ & $1.732)$ & 1.031 & 0.927 & $(0.539$ & 1.970) \\
\hline 18 & 2.872 & 0.062 & $(0.947$ & 8.706) & 1.058 & 0.884 & $(0.494$ & $2.265)$ & 1.425 & 0.372 & (0.655 & $3.101)$ & 2.717 & 0.001 & $(1.496$ & 4.935) \\
\hline 19 & 4.175 & 0.012 & $(1.377$ & 12.656) & 1.291 & 0.511 & $(0.603$ & 2.764) & 2.667 & 0.011 & $(1.255$ & 5.668) & 1.825 & 0.050 & $(1.001$ & 3.328) \\
\hline \multicolumn{17}{|l|}{ Province } \\
\hline Central & 1.000 & & & & 1.000 & & & & 1.000 & & & & 1.000 & & & \\
\hline Copperbelt & 1.345 & 0.544 & $(0.516$ & 3.504) & 2.671 & 0.017 & $(1.193$ & 5.978) & 1.262 & 0.640 & $(0.477$ & 3.341) & 0.904 & 0.750 & $(0.484$ & 1.687) \\
\hline Eastern & 3.147 & 0.017 & $(1.230$ & $8.052)$ & 1.425 & 0.425 & $(0.596$ & 3.406) & 2.257 & 0.062 & $(0.959$ & 5.311) & 0.937 & 0.817 & $(0.542$ & 1.620) \\
\hline Luapula & 0.539 & 0.319 & $(0.159$ & 1.819) & 3.234 & 0.004 & $(1.445$ & 7.238) & 0.390 & 0.117 & $(0.120$ & $1.265)$ & 0.602 & 0.161 & $(0.296$ & 1.224) \\
\hline Lusaka & 1.705 & 0.273 & $(0.657$ & $4.427)$ & 3.731 & 0.001 & $(1.671$ & 8.332) & 1.280 & 0.591 & $(0.521$ & $3.143)$ & 1.302 & 0.354 & $(0.745$ & $2.273)$ \\
\hline Muchinga & & & & & & & & & & & & & 0.793 & 0.472 & $(0.421$ & 1.493) \\
\hline Northern & 2.871 & 0.030 & (1.109 & 7.437) & 1.559 & 0.257 & $(0.724$ & 3.359) & 0.976 & 0.961 & $(0.375$ & $2.541)$ & 0.703 & 0.253 & $(0.384$ & $1.287)$ \\
\hline North western & 6.043 & 0.000 & $(2.301$ & 15.875) & 2.274 & 0.039 & $(1.041$ & 4.967) & 2.408 & 0.050 & $(1.000$ & $5.800)$ & 1.033 & 0.908 & $(0.592$ & 1.803) \\
\hline Southern & 1.302 & 0.619 & $(0.460$ & 3.688) & 1.763 & 0.189 & $(0.756$ & $4.110)$ & 1.108 & 0.822 & $(0.453$ & 2.713) & 1.110 & 0.719 & $(0.630$ & 1.954) \\
\hline Western & 2.301 & 0.080 & $(0.905$ & $5.853)$ & 1.735 & 0.208 & $(0.736$ & 4.093) & 5.967 & 0.000 & $(2.598$ & 13.706) & 1.406 & 0.238 & $(0.799$ & $2.475)$ \\
\hline \multicolumn{17}{|l|}{ Residence } \\
\hline Urban & 1.000 & & & & 1.000 & & & & 1.000 & & & & 1.000 & & & \\
\hline Rural & 0.556 & 0.040 & $(0.317$ & $0.974)$ & 0.827 & 0.422 & $(0.520$ & 1.315) & 0.658 & 0.051 & $(0.432$ & $1.002)$ & 0.654 & 0.002 & $(0.499$ & $0.859)$ \\
\hline \multicolumn{17}{|c|}{ Highest Level of Education } \\
\hline No Education & 1.000 & & & & 1.000 & & & & 1.000 & & & & 1.000 & & & \\
\hline Primary & 2.057 & 0.061 & $(0.968$ & $4.371)$ & 1.195 & 0.562 & $(0.655$ & $2.179)$ & 3.525 & 0.008 & $(1.386$ & $8.964)$ & 2.928 & 0.032 & $(1.099$ & $7.801)$ \\
\hline Secondary & 3.080 & 0.009 & $(1.322$ & $7.175)$ & 2.330 & 0.015 & $(1.179$ & 4.606) & 3.389 & 0.015 & $(1.263$ & $9.092)$ & 3.584 & 0.011 & $(1.333$ & $9.636)$ \\
\hline \multicolumn{17}{|l|}{ Current Marital Status } \\
\hline Never in union & 1.000 & & & & 1.000 & & & & 1.000 & & & & 1.000 & & & \\
\hline $\begin{array}{l}\text { Married/Living with } \\
\text { Partner }\end{array}$ & 1.934 & 0.003 & $(1.258$ & 2.975) & 2.867 & 0.000 & $(1.928$ & $4.263)$ & 2.408 & 0.000 & $(1.562$ & $3.712)$ & 4.131 & 0.000 & $(3.071$ & $5.559)$ \\
\hline $\begin{array}{l}\text { Widowed/ } \\
\text { Separated/Divorced }\end{array}$ & 0.708 & 0.551 & $(0.227$ & $2.207)$ & 0.837 & 0.727 & $(0.309$ & $2.271)$ & 3.199 & 0.016 & $(1.247$ & $8.208)$ & 1.423 & 0.351 & $(0.678$ & $2.984)$ \\
\hline \multicolumn{17}{|l|}{ Currently Working } \\
\hline No & 1.000 & & & & 1.000 & & & & 1.000 & & & & 1.000 & & & \\
\hline Yes & 1.614 & 0.023 & $(1.070$ & $2.436)$ & 1.276 & 0.243 & $(0.847$ & 1.921) & 1.392 & 0.127 & $(0.911$ & $2.127)$ & 1.345 & 0.037 & $(1.018$ & 1.777) \\
\hline sigma_u & 0.565 & & $(0.261$ & $1.223)$ & 0.004 & & $(0.000$ & $\begin{array}{l}120 \\
604.000)\end{array}$ & 0.005 & & $\begin{array}{l}(3.04 \mathrm{E}- \\
16\end{array}$ & $\begin{array}{l}8.78 \mathrm{E}- \\
10)\end{array}$ & 0.281 & & $(0.051$ & $1.538)$ \\
\hline rho & 0.088 & & $(0.020$ & $0.313)$ & 0.000 & & $(0.000$ & $1.000)$ & $\begin{array}{l}8.12 \mathrm{E}- \\
06\end{array}$ & & $\begin{array}{l}(2.81 \mathrm{E}- \\
32\end{array}$ & $1.000)$ & 0.023 & & $(0.001$ & $0.418)$ \\
\hline
\end{tabular}

contraception among adolescents could therefore be partly due to limited access to the right information and services.

Over the period 1996-2014, contraceptive use marginally increased with age. Adolescent girls aged 19 years were more likely to be using contraceptives at the time of the survey compared to 15 -year-olds. This finding is consistent with those from other studies $[8,29]$. This could be attributed to older female adolescents being more mature and knowledgeable about 
Table 5 Results from Collinearity Test

\begin{tabular}{lllllcl}
\hline & $\begin{array}{l}\text { Current Contraceptive } \\
\text { Use }\end{array}$ & Age & Province & Residence $\begin{array}{l}\text { Highest Level of } \\
\text { Education }\end{array}$ & $\begin{array}{c}\text { Current Marital } \\
\text { Status }\end{array}$ & $\begin{array}{c}\text { Currently } \\
\text { Working }\end{array}$ \\
\hline $\begin{array}{l}\text { Current Contraceptive } \\
\text { Use }\end{array}$ & 1 & & & & & \\
Age & 0.222 & 1 & & & \\
Province & 0.065 & 0.020 & 1 & & \\
Residence & -0.003 & -0.011 & 0.124 & 1 & 1 & 1 \\
Highest Level of & 0.001 & 0.091 & -0.016 & -0.361 & & 1 \\
Education & & & & & -0.25 & 0.177 \\
Current Marital Status & 0.257 & 0.353 & -0.026 & 0.144 & -0.202 & 1 \\
Currently Working & 0.099 & 0.134 & 0.103 & 0.216 & & \\
\hline
\end{tabular}

contraception and the importance of contraceptive use, unlike younger female adolescents. Furthermore, older female adolescents are more likely to be married, have higher education levels, and more likely to be active sexually compared to younger adolescents [30]. Adolescents who reported being married or living together with a man, or were separated, widowed, or divorced were more likely to use contraceptives compared to those who had never married. In recent surveys, adolescent girls who were separated, widowed, or divorced were also more likely to be using contraceptives compared to those who had never married. The findings are in line with those from other studies $[10,29,30]$. One study found that adolescent girls who were married or living with a man were significantly more likely to use contraception compared to those who were not married or living together with a partner [10]. Another study found that married adolescent girls had the highest odds of using contraceptives compared to those that never married or were formerly married [30, 31]. This could be due to partner support in using contraceptives among married women [32]. Married female adolescents may likely use contraceptives because they can afford more effective contraceptives than their unmarried counterparts due to financial support from the partner [10]. They are also more likely to practice family planning and take measures to prevent pregnancy compared to those who are not married due to regular exposure to sexual intercourse and the risk of unintended pregnancy.

The findings of this paper show that current contraceptive use increased with the level of education. Other studies have reported similar findings. Evidence shows that education affects contraceptive use among adolescents [18]. A study in Ghana found that the level of education was a significant factor in contraceptive use among women of reproductive age [33]. As the level of education increased, there was an increase in contraceptive use $[10,19]$. This increase was more so in urban areas where urban adolescents, who typically have higher education, report a higher likelihood of contraceptive use, particularly condoms [21]. Adolescents who are more educated are more likely to appreciate the advantage of having fewer children and how this can positively impact their own economic productivity and the well-being of their children [33, 34].

The results reported in this study have implications for both policy and public health in general. The increased likelihood of contraceptive use among adolescent girls with higher levels of education suggests that keeping girls longer in school is likely to improve their reproductive health outcomes. In addition, the introduction of comprehensive sexuality education in primary school curriculum in Zambia is vital for providing comprehensive and age-appropriate information to adolescents who are at a pivotal stage of their lives. However, it is vital to also target adolescents who are outside the school system. Community-based activities, in addition to youth-friendly spaces in health centres, are essential to ensure correct information is provided to adolescents.

Furthermore, access to contraceptives is another issue that needs to be addressed. Information centres, such as schools, can also serve as distribution points for contraceptives. The merits of distributing contraceptives in schools need to be explored further, in addition to distribution through youth-friendly spaces in health facilities. Generating demand for contraceptives and sexual and reproductive health services, as described in the 2017-2021 Zambia Adolescent Health Strategic Plan, is essential for increasing contraceptive use in this age group. Increasing the use of modern contraceptives is essential and has been shown to have a significant impact on fertility, and maternal, new-born, and child survival. Contraceptive use can significantly reduce unintended pregnancies, abortions, and births, as well as avert thousands of child and new-born deaths, including hundreds of maternal deaths, annually [35]. 


\section{Conclusion}

The findings of this paper show that contraceptive use among adolescent girls in Zambia has remained low over time, with only a modest increase from 8 to $11 \%$ between 1996 and 2013/14, which is much lower than the change in the general population. Over time, contraceptive use remained consistently low among younger, uneducated and unmarried sexually active adolescent girls, who comprise some of the disadvantaged sub-groups. In addition, whereas initial significant urban-rural differences in contraceptive use among adolescent girls did not occur in subsequent surveys, such differences began to emerge again in 2013/14. The findings suggest the need for targeted interventions to improve contraceptive use among sexually active adolescent girls in the country in general, and those who are disadvantaged in particular.

\section{Limitations}

The study had some inherent limitations and strengths. The study was based on DHS data from four surveys. Some variables included in the analysis have either changed or been added over time. Furthermore, DHS data is based on self-reporting, and there may be social desirability biases in some responses. In addition, given the cross-sectional nature of DHS, it is not possible to make causal inferences about the relationships observed in the data. Despite the limitations, the study highlights patterns in contraceptive use among adolescent girls in Zambia, which have important implications for programs aimed at improving reproductive health outcomes among this sub-group of the population. The study is also based on a nationally representative sample of adolescent girls, which allows for generalizing the findings to all adolescent girls in the country.

\begin{abstract}
Abbreviations
AOR: Adjusted odds ratio; Cl: Confidence interval; $\mathrm{CPH}$ : Census of population and housing; DHS: Demographic and health survey; LICs: Low income countries; UKZNBREC: University of KwaZulu natal biomedical research ethics committee; WHO: World health organization; ZDHS: Zambia demographic and health survey
\end{abstract}

\section{Acknowledgements}

The authors would like to thank the Demographic and Health Surveys (DHS) Program for granting permission to the datasets used in this study.

\section{Authors' contributions}

MC conceptualised the study, designed the methodology, led the formal data analysis and wrote the initial draft. $\mathrm{KH}$ and TGG reviewed the methodology, results of the study and reviewed the manuscript. KH and TGG supervised and approved the work. All authors have read and approved the manuscript.

\section{Funding}

This research was not funded.

\section{Availability of data and materials}

The data used in this paper are publicly available from the Demographic and Health Surveys (DHS) Program. Data can be accessed through their website https://dhsprogram.com/data/

\section{Ethics approval and consent to participate}

Ethical approval (REF No BE288/18) was obtained from the University of KwaZulu-Natal Biomedical Research Ethics Committee (UKZNBREC). Authorisation to use the data was obtained from Measure DHS via the DHS Program Website.

\section{Consent for publication}

Not applicable.

\section{Competing interests}

The authors declare that they have no competing interests.

Received: 22 July 2019 Accepted: 13 August 2020

Published online: 26 August 2020

\section{References}

1. World Health Organisation. Adolescent pregnancy [Internet]. 2018 [cited 2019 Apr 9]. Available from: https://www.who.int/news-room/fact-sheets/ detail/adolescent-pregnancy.

2. Darroch JE, Woog V, Bankole A, Ashford LS. Adding it up: costs and benefits of meeting contraceptive needs of adolescents. [Internet]. New York: Guttmacher Institute; 2016. Available from: https://www.guttmacher.org/ sites/default/files/report_pdf/adding-it-up-adolescents-report.pdf.

3. UNFPA. Adolescent pregnancy: a review of the evidence. New York: UNFPA; 2013.

4. Wado YD, Sully EA, Mumah JN. Pregnancy and early motherhood among adolescents in five east African countries: a multi-level analysis of risk and protective factors. BMC Pregnancy Childbirth [Internet]. 2019;19(1):59. Available from: https://doi.org/https://doi.org/10.1186/s12884-019-2204-z.

5. UNESCO. Early and unintended pregnancy \& the education sector: evidence review and recommendations. Paris: United Nations Educational, Scientific and Cultural Organization; 2017.

6. Kafle PP. Health problems and social consequences in teenage pregnancy in rural Kathmandu Valley. Nepal Med Coll J. 2010;12:42-4.

7. World Health Organization. Global health estimates 2013 summary tables: DALYS, YLLs and YLDs by cause, age and sex by WHO regional group and World Bank income classification, 2000--2012 (provisional estimates). Geneva: World Health Organization; 2014.

8. Hounton S, Barros AJD, Amouzou A, Shiferaw S, Maïga A, Akinyemi A, et al. Patterns and trends of contraceptive use among sexually active adolescents in Burkina Faso, Ethiopia, and Nigeria: Evidence from cross-sectional studies. Glob Health Action. 2015;8(1):29737 [cited 2018 Jan 22] Available from: https://www.tandfonline.com/doi/full/10.3402/gha.v8.29737.

9. Ngome E, Odimegwu C. The social context of adolescent women's use of modern contraceptives in Zimbabwe: a multilevel analysis. Reprod Health. 2014;11(1):64 [cited 2018 Jan 24] Available from: http://reproductive-healthjournal.biomedcentral.com/articles/10.1186/1742-4755-11-64.

10. Nyarko SH. Prevalence and correlates of contraceptive use among female adolescents in Ghana. BMC Womens Health [Internet]. 2015;15(1):60. [cited 2018 Jan 19] Available from: http://dx.doi.org/https://doi.org/10.1186/ s12905-015-0221-2.

11. Arthur MC, Champiti M. Sexual behaviour and contraceptive knowledge and use among female adolescents in Senior High School in Manhyia submetro, Kumasi. 2016 [cited 2018 Jan 22]; Available from: http://ir.knust. edu.gh/handle/123456789/8989.

12. PSI. Sexual and Reproductive Health of Adolescents and Youth [Internet]. 2016. Available from: http://www.psi.org/wp-content/uploads/2016/06/RH_ EvidenceSeries_d1.pdf.

13. Ahmed S. Others. Maternal deaths averted by contraceptive use: an analysis of 172 countries. Lancet. 2012;380:111-25.

14. Bhutta ZA. Others. Can available interventions end preventable deaths in mothers, newborn babies, and stillbirths, and at what cost? Lancet. 2014; 384:347-70.

15. Rutstein S, Winter R. Contraception needed to avoid high-fertility-risk births, and maternal and child deaths that would be averted. DHS analytical studies. No. 50. Rockville, Maryland, USA: ICF International; 2015. 
16. Canning D, Schultz TP. The economic consequences of reproductive health and family planning. Lancet. 2012;380:165-71.

17. Schultz TP, Joshi S. Family planning and women's and children's health: consequences of an outreach program in Matlab, Bangladesh. Demography. 2013;50:149-80.

18. Feleke SA, Koye DN, Demssie AF, Mengesha ZB. Reproductive health service utilization and associated factors among adolescents (15-19 years old) in Gondar town, Northwest Ethiopia. BMC Health Serv Res. 2013;13:294. Available from: http://dx.doi.org/https://doi.org/10.1186/ 1472-6963-13-294

19. Khan MM, Hossain ME, Hoq MN. Determinants of contraception use among female adolescents in Bangladesh. Asian Soc Sci. 2012;8:181-91.

20. Morris $J$, Rushwan $H$. Adolescent sexual and reproductive health: The global challenges. Int J Gynecol Obstet. 2015;131(S1):S40-2 [cited 2018 Jan 22] Available from: http://www.sciencedirect.com/science/article/pii/S002 0729215000855.

21. Doyle AM, Mavedzenge SN, Plummer ML, Ross DA. The sexual behaviour of adolescents in sub-Saharan Africa: patterns and trends from national surveys Revue: Comportement sexuel des adolescents en Afrique subsaharienne: Profils et tendances dans les enquêtes nationales Revisión: El comportamiento sexual. Trop Med Int Heal. 2012; 17:796-807. Available from: http://dx.doi.org/https://doi.org/10.1111/j. 1365-3156.2012.03005.x

22. Chandra-Mouli V, McCarraher DR, Phillips SJ, Williamson NE, Hainsworth G. Contraception for adolescents in low and middle income countries: needs, barriers, and access. Reprod Health. 2014;11:1. Available from: http://dx.doi. org/https://doi.org/10.1186/1742-4755-11-1.

23. Chipeta EK, Chimwaza W, Kalilani-Phiri L. Contraceptive knowledge, beliefs and attitudes in rural Malawi: misinformation, misbeliefs and misperceptions. Malawi Med J. 2010;22:38-41.

24. Ochako R, Mbondo M, Aloo S, Kaimenyi S, Thompson R, Temmerman M, et al. Barriers to modern contraceptive methods uptake among young women in Kenya: a qualitative study. BMC Public Health. 2015;15(1):118. [cited 2018 Jan 22] Available from: http://bmcpublichealth.biomedcentral. com/articles/https://doi.org/10.1186/s12889-015-1483-1.

25. Abubakari S, Enuameh YA, Mahama E, Nettey OEA, Adjei G, Nuamah GF, et al. Adolescents ' willingness and intentions to use contraceptives in Rural Ghana. Open J Soc Sci. 2015;3:239-49 [cited 2018 Jan 22]. Available from: https://www.researchgate.net/profile/Yeetey_Enuameh/publication/2841745 80_Adolescents'_Willingness_and_Intentions_to_Use_Contraceptives_in_ Rural_Ghana/links/5656b1c808ae4988a7b4f732.pdf.

26. Central Statistical Office (CSO) Tropical Diseases Research Centre (TDRC), M of $\mathrm{H}(\mathrm{MOH})$, University of Zambia and MII, Central statistical office (CSO) tropical diseases research Centre (TDRC), and ICF international M of H (MOH). Zambia demographic and health survey, vol. 2013-14. Calverton, Maryland, USA: CSO and Macro International Inc.; 2014.

27. Kennedy E, Gray N, Azzopardi P, Creati M. Adolescent fertility and family planning in East Asia and the Pacific: a review of DHS reports. Reprod Health. 2011;8:11. Available from: http://dx.doi.org/https://doi.org/10.1186/ 1742-4755-8-11.

28. Lebese RT, Maputle SM, Ramathuba DU, Khoza LB. Factors influencing the uptake of contraception services by Vatsonga adolescents in rural communities of Vhembe District in Limpopo Province, South Africa. Heal SA Gesondheid. 2013;18(1):6 Available from: http://dx.doi.org/10.4102/.

29. Subedi R, Jahan I, Baatsen P. Factors influencing modern contraceptive use among adolescents in Nepal. J Nepal Health Res Counc. 2018;16(3 SEReview Article) Available from: https://www.nepjol.info/index.php/JNHRC/ article/view/21419.

30. Palamuleni M. Trends and determinants of contraceptive use among female adolescents in Malawi. 2017;5239-350.

31. Ikamari LDE, Towett R. No TitleSexual initiation and contraceptive use among female adolescents in Kenya. Afr J Health Sci. 2008;14(1):1-13.

32. Harper C, Callegari L, Raine T, Blum M, Darney P. Adolescent clinic visits for contraception: support from mothers, male partners and friends. Perspect Sex Reprod Health. 2004;36(1):20-6.

33. Nketiah-Amponsah E, Arthur E, Abuosi ALB-N-A. Correlates of contraceptive use among Ghanaian women of reproductive age (15-49 years). Afri J Reprod Heal. 2012;16:154-69.

34. Okezie C, Ogbe AO, Okezie CR. Socio-economic determinants of contraceptive use among rural women in Ikwuano local government area of Abia state, Nigeria. Int NGO J. 2010;5(4):74-7.
35. Chola L, Pillay Y, Barron P, Tugendhaft A, Kerber K, Hofman K. Cost and impact of scaling up interventions to save lives of mothers and children: taking South Africa closer to MDGs 4 and 5. Glob Heal Action. 2015;8.

\section{Publisher's Note}

Springer Nature remains neutral with regard to jurisdictional claims in published maps and institutional affiliations.

\section{Ready to submit your research? Choose BMC and benefit from:}

- fast, convenient online submission

- thorough peer review by experienced researchers in your field

- rapid publication on acceptance

- support for research data, including large and complex data types

- gold Open Access which fosters wider collaboration and increased citations

- maximum visibility for your research: over $100 \mathrm{M}$ website views per year

At BMC, research is always in progress.

Learn more biomedcentral.com/submissions 